\title{
Immune Checkpoint Inhibitor ASP8374
}

National Cancer Institute

\section{Source}

National Cancer Institute. Immune Checkpoint Inhibitor ASP8374. NCI Thesaurus. Code C141421.

An immune checkpoint inhibitor with potential immunomodulating and antineoplastic activities. Although the exact target is undisclosed, ASP8374 inhibits the activity of an immune checkpoint protein, which ultimately leads to the activation of a cytotoxic Tlymphocyte (CTL)-mediated immune response against cancer cells. 